介護予防事業による栄養改善プログラム参加者の 食事・食生活・運動器機能の改善効果

森脇弘子* · 水馬朋子** · 梯 正之***

("県立広島大学人間文化学部, ${ }^{* *}$ 県立広島大学保健福祉学部, ***広島大学大学院医歯薬保健学研究院)

\title{
The effectiveness of the dietary and musculoskeletal function in a nutritional improvement program for preventive care service under long-term care insurance
}

\author{
Hiroko Moriwaki*, Tomoko Mizuma**, Masayuki Kakehashi* \\ * Faculty of Human Culture and Science, Prefectural University of Hiroshima, \\ 1-1-71, Ujinahigashi, Minami-ku, Hiroshima-shi, Hiroshima, 734-8558 \\ ** Faculty of Health and Welfare, Prefectural University of Hiroshima, \\ 1-1, Gakuen-cho, Mihara-shi, Hiroshima, 723-0053 \\ *** Institute of Biomedical and Health Sciences, Hiroshima University, \\ 1-2-3, Kasumi, Minami-ku, Hiroshima-shi, Hiroshima, 734-8553

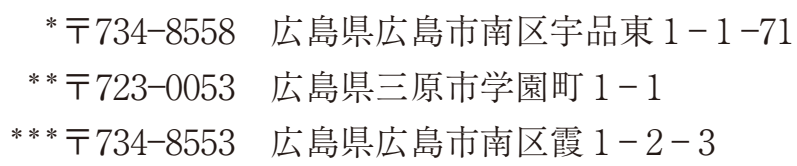

In recent years, the Japanese population has been rapidly aging. We examined the effectiveness of a nutritional improvement program designed to enable elderly individuals to live independently in their community.

We conducted pre- and post-assessments on 203 community-living elderly individuals who participated in a nutritional improvement program. We divided the participants into a low-scoring group and the other group based on their "dietary status score" from a pre-assessment.

The results from this study are summarized as follows:

1) Men and women in the low-scoring group had a better "dietary status score" after the nutritional improvement program. Moreover, the "daily consumption of a dish cooked in oil" became more prevalent among the men and women. The "dietary habits score (enjoyment of meals, and favorability of current dietary habits)" of the men in the low-scoring group also improved.

2) TUG (Timed Up and Go Test) improved among the men and women in the lowscoring group, and women in the other group.

The nutritional improvement program was shown to be effective for participants who had a low "dietary status score”, therefore, it may contribute to preventive care. 


\section{1. 緒言}

わが国では近年，急激な高齢化が進んでいる。内閣府 によると，わが国における65歳以上の高齢者が総人口に 占める割合は年々上昇し続け，2014年には $26.0 \%$ だ上 昇している。その後も総人口が減少する中で高齢者が増 加することにより高齢化率は上昇を続け，2035年には高 齢化率が $33.4 \%$ ，国民の 3 人に 1 人が高齢者になると推 計されている11。

このような超高齢社会に対して，2000年度から実施さ れた介護保険制度は，2006年度の法改正に伴い予防重視 型システムへ移行し，高齢者が地域で自立して生活する ことができるようにすることを目的に，要支援・要介護 状態等となる恐れのある高齢者を早期に把握し, 水際で 食い止める介護予防事業が重視されようになった。介護 予防事業は要支援・要介護に陥るリスクの高い高齢者を 対象にした二次予防事業と，活動的な状態にある高齢者 を対象としできるだけ長く生きがいをもち地域で自立し た生活を送ることができるようにすることを支援する一 次予防事業で構成されている。二次予防事業の一つであ る栄養改善プログラムは日常生活の食事を通じて, 高齢 者自らが低栄養状態の改善および重症化予防を図ること を支援し，低栄養の予防により生活機能を維持すること を意図している ${ }^{2)}$ 。

一般に高齢者は加齢に伴い低栄養状態の出現率が増加 することが明らかになっている。高齢者の低栄養状態は 感染症リスクの増大 ${ }^{3)}$, QOL (quality of life：生活の質） ADL (activities of daily living : 日常生活動作) や IADL (instrumental activity of daily living : 手段的日常生活動

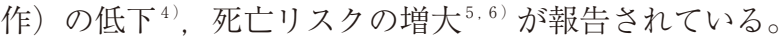
現在，二次予防事業を対象とした研究の多くは運動器 の機能改善を検討したもので7)，栄養改善についての検 討は久喜ら ${ }^{8)}$ の栄養改善プログラムの効果, 深作ら ${ }^{9)}$ 田口ら ${ }^{10)}$ の運動および栄養改善プログラムによる介護予 防効果，馬庭ら ${ }^{11)}$ の牛乳摂取による介護予防効果の検討 などと少ない。これらの研究では，栄養改善プログラム の対象者全体の食事・食生活や栄養状態の改善効果は示
されているが，対象者の中でも特に食事・食生活や栄養 状態が不良な者に改善効果があるのか, そうでない良好 な者の改善効果であるのかについては検討されていない。

そこで，本研究は広島県内の介護予防事業における栄 養改善プログラムや栄養改善を含む複合プログラム参加 者を対象に食事・食生活および運動器機能等を調査し, プログラム実施前後の比較から改善効果を検討すること を目的とした。

\section{2. 方 法}

（1）調査対象, 調査時期，プログラム内容および調査 方法

調査対象は，広島県内の協力の得られた市町および介 護予防事業委託事業者のうち, 介護予防事業 (二次予防) として実施した栄養改善プログラムまたは栄養改善プロ グラムを含む 2 種類の複合プログラムに参加した 6 市町 698名とした。このうち，調査票を回収できた人数は548 名，属性とプログラム実施前後の食事内容得点の不明な 者を除く203名（男性53名，女性150名）を解析対象者（以 下，「対象者」とする）とした（有効回答 $29.1 \%$ )。

参加プログラム別対象者を表 1 に示した。男女を合わ せた対象者数は栄養改善11名 (5.4\%), 栄養改善・口腔 機能向上の複合プログラム 3 名 $(1.5 \%)$, 運動器機能向 上・栄養改善・口腔機能向上の複合プログラム 189 名 (93.1\%)，であった。栄養改善プログラムの男性，栄養 改善・ 口腔機能向上プログラムの男女は対象者が 2 名以 下と少なく，プログラム別の解析が難しく，プログラム 別に集計した結果に大きな差がみられなかったため， 3 つのプログラムを合計し，集計・解析した。

調査時期は平成 24 年 4 月から 12 月，プログラム実施期 間は約 3 か月間であった。

栄養改善プログラムは介護予防マニュアル改訂版 ${ }^{2)}$ に 準じ $1 \sim 2$ 週間に 1 回, 計 5 回程度, 約 90 分行った。 2 ・ 3 回程度の個別指導と, 小グループでの栄養相談, 集団 的プログラムを組み合わせた。実習テーマは表 2 より選 択した ${ }^{2,12)}$ 。

栄養改善・口腔機能向上の複合プログラムは広島県介

表 1 参加プログラム別 対象者

\begin{tabular}{cccc}
\hline & 栄養改善 & $\begin{array}{c}\text { 栄養改善 } \\
\text { 口腔機能向上 }\end{array}$ & $\begin{array}{c}\text { 運動器機能向上· } \\
\text { 栄養改善・ } \\
\text { 口腔機能向上 }\end{array}$ \\
\hline 男 低評価 $(n=21)$ & 0 & 1 & 20 \\
性 その他 $(n=32)$ & 1 & 1 & 30 \\
\hline 女 低評価 $(n=30)$ & 1 & 0 & 29 \\
肴 その他 $(n=120)$ & 9 & 1 & 110 \\
\hline 計 & 11 & 3 & 189 \\
$(\%)$ & $(5.4)$ & $(1.5)$ & $(93.1)$ \\
\hline
\end{tabular}

$n:$ 人数 $(\%)$ 
介護予防事業による栄養改善プログラム参加者の食事・食生活・運動器機能の改善効果

表 2 学習・実習テーマー覧

\begin{tabular}{|c|c|c|c|}
\hline \multicolumn{2}{|r|}{ 栄養改善プログラム } & \multicolumn{2}{|r|}{ 口腔機能向上プログラム } \\
\hline テーマ & 内容 & テーマ & 内容 \\
\hline 多様性 & $\begin{array}{l}\text { バランスの良い食事で元気な毎日を } \\
\text { はやくて簡単バランス食 その } 1\end{array}$ & 舌 & $\begin{array}{l}\text { 舌の観察・ロ腔乾燥と味覚チェック } \\
\text { 唾液腺マッサージ, 健口体操 }\end{array}$ \\
\hline 調味料 & $\begin{array}{l}\text { 調味料を上手に使って作ろう } \\
\text { はやくて簡単バランス食 その } 2\end{array}$ & 唾液 & $\begin{array}{l}\text { 歯肉マッサージ, 健口体操 } \\
\text { 唾液腺マッサージ }\end{array}$ \\
\hline 主食 & $\begin{array}{l}\text { エネルギーのもと ごはん } \\
\text { 楽しんでつくるバランス食 その } 1\end{array}$ & 咀嚼 & 30回咀嚼, 嚥下体操 \\
\hline 主菜 & $\begin{array}{l}\text { 若さを保つ肉・魚·卵・大豆のおかず } \\
\text { 楽しんでつくるバランス食 その } 2\end{array}$ & 嚥下 & $\begin{array}{l}\text { 嚥下機能トレーニング } \\
\text { 燕下体操 }\end{array}$ \\
\hline 副菜 & $\begin{array}{l}\text { からだの調子をよくする野菜のおかず } \\
\text { ひと手間かけたバランス食 }\end{array}$ & 歯 & $\begin{array}{l}\text { 歯みがきのススメと虫歯の実験 } \\
\text { パタカラ体操 }\end{array}$ \\
\hline 健康 & $\begin{array}{l}\text { 上手にとりたい油と脂 } \\
\text { ひと手間かけたバランス食 その } 2\end{array}$ & 笑顔 & $\begin{array}{l}\text { 顔じゃんけん, 吹矢 } \\
\text { パタカラ体操 }\end{array}$ \\
\hline
\end{tabular}

護予防実践マニュアル ${ }^{12)}$ に準じ， $1 ２$ 週に 1 回，計10 回程度行った。口腔機能向上または栄養改善プログラム を約90分, 各 5 回程度実施した。学習・実習テーマは表 2 上り選択し ${ }^{2.122}$, 口腔機能向上プログラムは口腔清掃 の自立支援，摂食・嬹下機能等の向上支援を行った。

運動器機能向上・栄養改善・ 口腔機能向上の複合プロ グラムは介護予防マニュアル改訂版 ${ }^{2)}$ に準じ, 週 1 回計 12回程度行った。1 回のプログラムは, 運動器の機能向 上プログラムを約30分 (準備運動, 主運動, 整理運動) 毎回行った後, 口腔機能向上または栄養改善プログラム を約90分, 各 5 回程度実施した。運動器の機能向上プロ グラムは, ストレッチング・バランス運動・機能的運 動・筋力向上運動等を組み合わせて実施し, 進行にした がって徐々に強度・複雑さが増すようにした。

いずれのプログラムも同一の栄養改善プログラムを含 んでいた。各々のプログラムは，対象者が目標を設定し， プログラムの内容が自宅でも習慣化されるよう具体的で 実践可能な資料を提供した。各実施場所により地域特性 があり，施設の設備や人材などが異なることより詳細な 内容は統一できなかった。

調査はプログラム実施の 1 回目 (以下,「プログラム前」 とする）と最終回（以下，「プログラム後」とする）に 行い，質問項目は自記式にて，測定項目はプログラム担 当者が測定し記入した。

対象者には，調查の趣旨を十分説明したうえで，デー 夕提供の同意を得た。調查票の配布・回収はプログラム 担当者が行い匿名化した上で，市町と県を経由し研究者 らに提供された。な挹, 本研究は県立広島大学研究倫理 審査委員会 (人間文化) で承認を受けている $(13 \mathrm{HH} 001)$ 。

\section{（2）調查内容}

調査内容は, 属性 (年齢, 身長, 体重), 食事内容 7 項目抢よび食生活状況 2 項目, 運動器機能（握力, 開眼
片足立ち, Timed Up \& Go Test）とした。これらは栄養 改善マニュアル (改訂版 $)^{13)}$ 介護予防マニュアル改訂版 ${ }^{2)}$ のアセスメント項目を参考に設定した。低栄養状態等に 係る食生活上の課題を見つけ出すために，食事内容とし て食事回数, 主食, 主菜, 副菜, 牛乳·乳製品, 果物, 油の摂取について質問した。食生活状況として食事への 意欲や食生活の自己評価を調べるために，「食事を楽し く食べていますか」，「現在の食生活をどのように思いま すか」について尋ねた。運動器機能は身体全体の筋力の 目安として握力, バランス能力の確認として開眼片足立 ち, 複合的動作能力として椅子から立ち上がり $3 \mathrm{~m}$ 先 の目印を折り返し，再び椅子に座るまでの時間を計測す る Timed Up \& Go Test（以下，「TUG」とする）を測定 した。各運動器機能は 2 回測定し，良好な值を採用した。

\section{（3）集計および解析方法}

プログラム前の食事内容 7 項目について 3 選択肢より 回答を求め,「ほぼ毎日食べる/毎食食べる」を 2 点, 「週 に 3〜 4 日程度食べる/ 1 日に $1 〜 2$ 食程度食べる」を 1 点,「ほとんど食べない」を 0 点とし (表 4 参照)，合 計点数を求め食事内容得点とした（14点満点）。また, 食生活状況 2 項目についても同様に 3 選択肢より回答を 求め, 得点化し, 合計点数を食生活状況得点とした (4 点満点)。

対象者のプログラム前の食事内容得点の分布は図 1 に 示すと抢りであり, 平均は $11.8 \pm 1.8$ 点であった。全体 として下位約 $25 \% の 11$ 点未満の者を「低評価群」, 11点 以上の者を「その他群」に分類し集計を行った（以下，「低 評価群」,「その他群」とする)。

属性については低評価群とその他群の 2 群間の比較を 対応のない $t$ 検定で行った。食事内容・食生活状況につ いては低評価群とその他群の改善効果を検討するため, 各質問項目について 2 群別にプログラム実施前後のクロ 


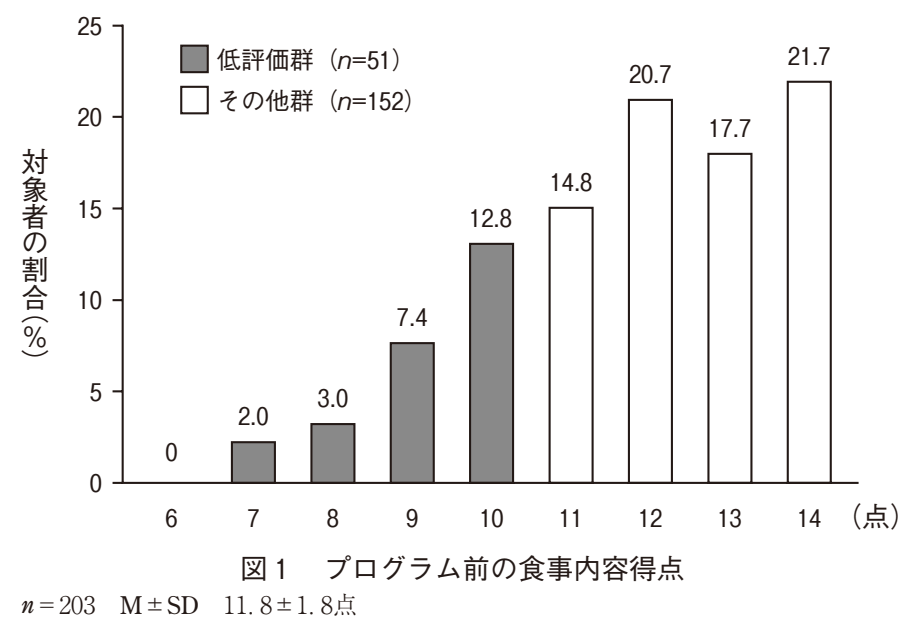

表 3 対象者の属性

\begin{tabular}{lcccrrr}
\hline & \multicolumn{3}{c}{ 男性 $(n=53)$} & \multicolumn{3}{c}{ 女性 $(n=150)$} \\
\cline { 2 - 6 } & \multicolumn{1}{c}{$\begin{array}{c}\text { 低評価群 } \\
n=21\end{array}$} & $\begin{array}{c}\text { その他群 } \\
n=32\end{array}$ & $p$ 值 ${ }^{1)}$ & $\begin{array}{c}\text { 低評価群 } \\
n=30\end{array}$ & $\begin{array}{c}\text { その他群 } \\
n=120\end{array}$ & $p_{\text {值 }}{ }^{1)}$ \\
\hline 年齢 $($ 歳 $)$ & $76.3 \pm 5.5$ & $77.9 \pm 7.0$ & 0.485 & $79.9 \pm 4.4$ & $77.8 \pm 5.3$ & 0.114 \\
身長 $(\mathrm{cm})$ & $161.4 \pm 6.2$ & $160.0 \pm 7.1$ & 0.470 & $146.4 \pm 5.8$ & $147.6 \pm 5.5$ & 0.278 \\
体重 $(\mathrm{kg})$ & $57.7 \pm 8.8$ & $58.4 \pm 8.3$ & 0.759 & $51.4 \pm 10.6$ & $50.6 \pm 7.6$ & 0.605 \\
$\mathrm{BMI}\left(\mathrm{kg} / \mathrm{m}^{2}\right)$ & $22.1 \pm 2.8$ & $22.8 \pm 2.8$ & 0.363 & $24.0 \pm 4.6$ & $23.2 \pm 3.3$ & 0.295 \\
$\mathrm{BMI}<18.5(\%)$ & 14.3 & 9.4 & 0.581 & 13.3 & 6.7 & 0.229 \\
\hline
\end{tabular}

平均土標準偏差

1）対応のない $t$ 検定，ただし $\mathrm{BMI}<18.5 （ \%)$ の $\chi^{2}$ 検定

ス集計を行い，McNemar-Bowker 検定を行った。また， 食事内容抢よび食生活状況を点数化して得点を求め, プ ログラム実施前後で対応のある検定を行うためWilcoxon 符号付順位検定にて検討した。さらにプログラム実施前 後の身体状況，および運動器機能の測定值は対応のある $t$ 検定, プログラム前の測定值は対応のない $t$ 検定を行っ た。

データの集計解析には, 統計パッケージ IBM SPSS Statistics ver.21.0（日本アイ・ビー・エム株式会社）を 使用し，有意水準は $5 \%$ 未満とした。

\section{3. 結 果}

\section{（1）対象者の属性}

プログラム前に調査した対象者の属性を表 3 に示した。 男性は低評価群21名 (39.6\%), その他群32名 (60.4\%), 女性は各々 30 名 (20.0\%)，120名（80.0\%）であった。 年齢 (平均土標準偏差) は, 男性は低評価群 $76.3 \pm 5.5$ 歳, その他群 $77.9 \pm 7.0$ 歳, 女性は各々 $79.9 \pm 4.4$ 歳, $77.8 \pm$ 5. 3歳, BMI は, 男性は各々 $22.1 \pm 2.8,22.8 \pm 2.8$, 女 性は各々 $24.0 \pm 4.6,23.2 \pm 3.3$ であった。年齢, 身長,

体重, BMI は2 群間で男女ともに差は認められなかった。 BMI18.5未満の割合 $(\mathrm{BMI}<18.5(\%))$ は, 男性は低 評価群 $14.3 \%$, その他群 $9.4 \%$, 女性は各々 $13.3 \%, 6.7 \%$ であり，低評価群が高かったが 2 群間で男女とも有意な
差は認められなかった。

\section{（2）低評価群とその他群のプログラム実施前後の食事 内容および食生活状況の変化}

低評価群とその他群別にプログラム実施前後の食事内 容·食生活状況の変化を表 4 に示した。

男性に扔いて，食事内容の各項目は，低評価群の「油 を使った料理を毎日食べますか」に有意差が認められた $(p<0.01)$ 。「ほほ毎日食べる」者の割合がプログラム前 $4.8 \%$ からプログラム後 $38.1 \%$ に改善した。食事内容の 7 項目を合計した食事内容得点（平均土標準偏差）は, 低評価群がプログラム前 $9.4 \pm 0.9$ 点, プログラム後 10.4 \pm 2.0 点であり, 有意に改善した $(\boldsymbol{p}<0.05)$ 。その他群 には食事内容の各項目, 得点ともにプログラム実施前後 の差は認められなかった。食生活状況の各項目は, 低評 価群・その他群ともにプログラム実施前後に有意差はみ られなかったが，それら 2 項目を合計した食生活状況得 点は, 低評価群がプログラム前 $2.4 \pm 1.0$ 点, プログラム 後 $2.7 \pm 1.0$ 点であり, 有意に改善した $(p<0.05)$ 。

女性に打いても，「油を使った料理を毎日食べますか」 に有意差が認められ $(p<0.05)$,「ほぼ毎日食べる」者 の割合がプログラム前 $23.3 \%$ から後 $36.7 \%$ に改善した。 食事内容得点 (平均士標準偏差) は, 低評価群がプログ ラム前 $9.1 \pm 1.0$ 点, プログラム後 $10.8 \pm 1.9$ 点であり， 
介護予防事業による栄養改善プログラム参加者の食事・食生活・運動器機能の改善効果

表 4-1 プログラム実施前後の食事内容・食生活状況の変化（男性）

\begin{tabular}{|c|c|c|c|c|c|c|c|c|c|c|c|c|}
\hline & \multirow[b]{3}{*}{ 選択肢 } & \multirow[b]{3}{*}{ 点数 } & \multicolumn{5}{|c|}{ 低評価群 $n=21$} & \multicolumn{5}{|c|}{ その他群 $n=32$} \\
\hline & & & \multicolumn{2}{|c|}{ 前 } & \multicolumn{2}{|c|}{ 後 } & \multirow{2}{*}{$\begin{array}{l}p \text { 值 } \\
\text { 前後間 }\end{array}$} & \multicolumn{2}{|c|}{ 前 } & \multicolumn{2}{|c|}{ 後 } & \multirow{2}{*}{$\begin{array}{l}p \text { 值 } \\
\text { 前後間 }\end{array}$} \\
\hline & & & $n$ & $\%$ & $n$ & $\%$ & & $n$ & $\%$ & $n$ & $\%$ & \\
\hline \multicolumn{13}{|l|}{ 〈食事内容〉 } \\
\hline \multirow[t]{3}{*}{1 日に食事を 3 食食べますか } & ほぼ毎日食べる & 2 & 19 & 90.5 & 19 & 90.5 & - & 31 & 96.9 & 31 & 96.9 & - \\
\hline & 3-4日 / 週程度食べる & 1 & 1 & 4.8 & 1 & 4.8 & & 0 & 0.0 & 1 & 3.1 & \\
\hline & ほとんど食べない & 0 & 1 & 4.8 & 1 & 4.8 & & 1 & 3.1 & 0 & 0.0 & \\
\hline \multirow[t]{3}{*}{ 主食を毎食食べますか } & ほぼ毎食食べる & 2 & 20 & 95.2 & 19 & 90.5 & 1.000 & 32 & 100.0 & 31 & 96.9 & - \\
\hline & 1-2食/日程度食べる & 1 & 1 & 4. 8 & 2 & 9.5 & & 0 & 0.0 & 1 & 3. 1 & \\
\hline & ほとんど食べない & 0 & 0 & 0.0 & 0 & 0.0 & & 0 & 0.0 & 0 & 0.0 & \\
\hline \multirow[t]{3}{*}{ 主菜を毎食食べますか } & ほぼ毎食食べる & 2 & 12 & 57.1 & 14 & 66.7 & 0.261 & 25 & 78.1 & 26 & 81.3 & 1.000 \\
\hline & 1-2食/日程度食べる & 1 & 8 & 38.1 & 5 & 23.8 & & 7 & 21.9 & 6 & 18.8 & \\
\hline & ほとんど食べない & 0 & 1 & 4.8 & 2 & 9.5 & & 0 & 0.0 & 0 & 0.0 & \\
\hline \multirow[t]{3}{*}{ 副菜を毎食食べますか } & ほぼ毎食食べる & 2 & 11 & 52.4 & 14 & 66.7 & 0.453 & 27 & 84.4 & 26 & 81.3 & 1.000 \\
\hline & 1-2食/日程度食べる & 1 & 10 & 47.6 & 7 & 33.3 & & 5 & 15.6 & 6 & 18.8 & \\
\hline & ほとんど食べない & 0 & 0 & 0.0 & 0 & 0.0 & & 0 & 0.0 & 0 & 0.0 & \\
\hline \multirow[t]{3}{*}{ 牛乳・乳製品を毎日食べますか } & ほぼ毎日食べる & 2 & 5 & 23.8 & 7 & 33.3 & 0.261 & 21 & 65.6 & 21 & 65.6 & 0.513 \\
\hline & 3-4日 / 週程度食べる & 1 & 6 & 28.6 & 7 & 33.3 & & 7 & 21.9 & 8 & 25.0 & \\
\hline & ほとんど食べない & 0 & 10 & 47.6 & 7 & 33.3 & & 4 & 12.5 & 3 & 9.4 & \\
\hline \multirow[t]{3}{*}{ 果物を毎日食べますか } & ほぼ毎日食べる & 2 & 5 & 23.8 & 8 & 38.1 & 0.261 & 21 & 65.6 & 19 & 59.4 & 0.717 \\
\hline & 3-4日 / 週程度食べる & 1 & 9 & 42.9 & 9 & 42.9 & & 10 & 31.3 & 12 & 37.5 & \\
\hline & ほとんど食べない & 0 & 7 & 33.3 & 4 & 19.0 & & 1 & 3.1 & 1 & 3.1 & \\
\hline \multirow[t]{3}{*}{ 油を使った料理を毎日食べますか } & ほぼ毎日食べる & 2 & 1 & 4.8 & 8 & 38.1 & 0.008 & 16 & 50.0 & 19 & 59.4 & 0.247 \\
\hline & 3-4日 / 週程度食べる & 1 & 15 & 76.2 & 9 & 42.9 & & 13 & 40.6 & 11 & 34.4 & \\
\hline & ほとんど食べない & 0 & 4 & 19.0 & 4 & 19.0 & & 3 & 9.4 & 2 & 6.3 & \\
\hline \multicolumn{2}{|l|}{ 食事内容得点 $(\text { 合計；点 })^{1)}$} & & \multicolumn{2}{|c|}{$9.4 \pm 0.9$} & \multicolumn{2}{|c|}{$10.4 \pm 2.0$} & 0.020 & \multicolumn{2}{|c|}{$12.1 \pm 1.1$} & \multicolumn{2}{|c|}{$12.2 \pm 1.2$} & 0.592 \\
\hline \multirow{4}{*}{$\begin{array}{l}\text { 〈食生活状況〉 } \\
\text { 食事を楽しく食べていますか }\end{array}$} & & & & & & & & & & & & \\
\hline & 楽しい & 2 & 10 & 47.6 & 12 & 57.1 & - & 23 & 71.9 & 22 & 68.8 & 1. 000 \\
\hline & どちらともいえない & 1 & 9 & 42.9 & 9 & 42.9 & & 9 & 28.1 & 10 & 31.3 & \\
\hline & 楽しくない & 0 & 2 & 9.5 & 0 & 0.0 & & 0 & 0.0 & 0 & 0.0 & \\
\hline \multirow{3}{*}{$\begin{array}{l}\text { 現在の食生活をどのように思いま } \\
\text { すか }\end{array}$} & 良い & 2 & 2 & 9.5 & 5 & 23.8 & 0.223 & 13 & 40.6 & 9 & 28.1 & 0.082 \\
\hline & 普通 & 1 & 17 & 81.0 & 14 & 66.7 & & 16 & 50.0 & 21 & 65.6 & \\
\hline & 問題がある & 0 & 2 & 9.5 & 2 & 9.5 & & 3 & 9.4 & 2 & 6.3 & \\
\hline \multicolumn{2}{|l|}{ 食生活状況得点 (合計；点 $)^{1)}$} & & $2.4 \pm$ & & $2.7 \pm$ & & 0.038 & $3.0 \pm$ & & $2.9 \pm 0$ & & 0.157 \\
\hline
\end{tabular}

1) 平均土標準偏差。Wilcoxon 符号付順位検定，それ以外は McNemar-Bowker 検定

表 4-2 プログラム実施前後の食事内容・食生活状況の変化（女性）

\begin{tabular}{|c|c|c|c|c|c|c|c|c|c|c|c|c|}
\hline & \multirow[b]{3}{*}{ 選択肢 } & \multirow[b]{3}{*}{ 点数 } & \multicolumn{5}{|c|}{ 低評価群 $n=30$} & \multicolumn{5}{|c|}{ その他群 $n=120$} \\
\hline & & & \multicolumn{2}{|c|}{ 前 } & \multicolumn{2}{|c|}{ 後 } & \multirow{2}{*}{$\begin{array}{l}p \text { 值 } \\
\text { 前後間 }\end{array}$} & \multicolumn{2}{|c|}{ 前 } & \multicolumn{2}{|c|}{ 後 } & \multirow{2}{*}{$\begin{array}{l}p \text { 值 } \\
\text { 前後間 }\end{array}$} \\
\hline & & & $n$ & $\%$ & $n$ & $\%$ & & $n$ & $\%$ & $n$ & $\%$ & \\
\hline \multicolumn{13}{|l|}{ 〈食事内容〉 } \\
\hline \multirow[t]{3}{*}{1 日に食事を 3 食食べますか } & ほぼ毎日食べる & 2 & 26 & 86.7 & 29 & 96.7 & 0.250 & 118 & 98.3 & 118 & 98.3 & 1.000 \\
\hline & 3-4日 / 週程度食べる & 1 & 4 & 13.3 & 1 & 3.3 & & 2 & 1.7 & 2 & 1.7 & \\
\hline & ほとんど食べない & 0 & 0 & 0.0 & 0 & 0.0 & & 0 & 0.0 & 0 & 0.0 & \\
\hline \multirow[t]{3}{*}{ 主食を毎食食べますか } & ほほ毎食食べる & 2 & 28 & 93.3 & 28 & 93.3 & 1. 000 & 116 & 96.7 & 113 & 94.2 & 0.453 \\
\hline & 1-2食/日程度食べる & 1 & 2 & 6.7 & 2 & 6.7 & & 4 & 3.3 & 7 & 5.8 & \\
\hline & ほとんど食べない & 0 & 0 & 0.0 & 0 & 0.0 & & 0 & 0.0 & 0 & 0.0 & \\
\hline \multirow{3}{*}{ 主菜を毎食食べますか } & ほぼ毎食食べる & 2 & 3 & 10.0 & 11 & 36.7 & 0.059 & 100 & 83.3 & 97 & 80.8 & - \\
\hline & 1-2食/日程度食べる & 1 & 24 & 80.0 & 18 & 60.0 & & 19 & 15.6 & 23 & 19.2 & \\
\hline & ほとんど食べない & 0 & 3 & 10.0 & 1 & 3.3 & & 1 & 0.8 & 0 & 0.0 & \\
\hline \multirow[t]{3}{*}{ 副菜を毎食食べますか } & ほぼ毎食食べる & 2 & 11 & 36.7 & 18 & 60.0 & - & 103 & 85.8 & 97 & 80.8 & - \\
\hline & 1-2食/日程度食べる & 1 & 18 & 60.0 & 12 & 40.0 & & 17 & 14.2 & 22 & 18.3 & \\
\hline & ほとんど食べない & 0 & 1 & 3.3 & 0 & 0.0 & & 0 & 0.0 & 1 & 0.8 & \\
\hline \multirow[t]{3}{*}{ 牛乳・乳製品を毎日食べますか } & ほぼ毎日食べる & 2 & 11 & 36.7 & 14 & 46.7 & 0.112 & 100 & 83.3 & 100 & 83.3 & 0.135 \\
\hline & 3-4日 / 週程度食べる & 1 & 7 & 23.3 & 8 & 26.7 & & 11 & 9.2 & 15 & 12.5 & \\
\hline & ほとんど食べない & 0 & 12 & 40.0 & 8 & 26.7 & & 9 & 7.5 & 5 & 4.2 & \\
\hline \multirow[t]{3}{*}{ 果物を毎日食べますか } & ほぼ毎日食べる & 2 & 12 & 40.0 & 19 & 63.3 & 0.090 & 87 & 72.5 & 89 & 74.2 & 0.338 \\
\hline & 3-4日 / 週程度食べる & 1 & 12 & 40.0 & 7 & 23.3 & & 30 & 25.0 & 30 & 25.0 & \\
\hline & ほとんど食べない & 0 & 6 & 20.0 & 4 & 13.3 & & 3 & 2.5 & 1 & 0.8 & \\
\hline \multirow[t]{3}{*}{ 油を使った料理を毎日食べますか } & ほぼ毎日食べる & 2 & 7 & 23.3 & 11 & 36.7 & 0.029 & 83 & 69.2 & 84 & 70.0 & 0.595 \\
\hline & 3-4日 / 週程度食べる & 1 & 11 & 36.7 & 16 & 53.3 & & 33 & 27.5 & 34 & 28.3 & \\
\hline & ほとんど食べない & 0 & 12 & 40.0 & 3 & 10.0 & & 4 & 3.3 & 2 & 1.7 & \\
\hline \multicolumn{2}{|l|}{ 食事内容得点 $(\text { 合計 ; 点 })^{1)}$} & & \multicolumn{2}{|c|}{$9.1 \pm 1.0$} & \multicolumn{2}{|c|}{$10.8 \pm 1.9$} & $<0.001$ & \multicolumn{2}{|c|}{$12.8 \pm 1.1$} & \multicolumn{2}{|c|}{$12.7 \pm 1.4$} & 0.778 \\
\hline \multirow{4}{*}{$\begin{array}{l}\langle\text { 〈食生活状況〉2) } \\
\text { 食事を楽しく食べていますか }\end{array}$} & & & & & & & & & & & & \\
\hline & 楽しい & 2 & 17 & 58.6 & 19 & 65.5 & 0.607 & 91 & 75.8 & 98 & 81.7 & 0.247 \\
\hline & どちらともいえない & 1 & 11 & 37.9 & 9 & 31.0 & & 27 & 22.5 & 21 & 17.5 & \\
\hline & 楽しくない & 0 & 1 & 3.4 & 1 & 3.4 & & 2 & 1.7 & 1 & 0.8 & \\
\hline 現在の食生活をどのように思いま & 良い & 2 & 5 & 17.2 & 7 & 24.1 & 0.157 & 50 & 41.7 & 54 & 45.0 & 0.641 \\
\hline \multirow{2}{*}{ すか } & 普通 & 1 & 22 & 75.9 & 20 & 69.0 & & 67 & 55.8 & 63 & 52.5 & \\
\hline & 問題がある & 0 & 2 & 6.9 & 2 & 6.9 & & 3 & 2.6 & 3 & 2.5 & \\
\hline 食生活状況得点 (合計 ; 点 $)^{1)}$ & & & $2.7 \pm$ & & $2.8 \pm$ & & 0.206 & $3.1 \pm$ & & $3.2 \pm 0$ & & 0.076 \\
\hline
\end{tabular}

1）平均土標準偏差。Wilcoxon 符号付順位検定，それ以外は McNemar-Bowker 検定

2) 表中に不明の者を記していない。 
表 5 プログラム実施前後の身体状況・運動器機能の変化

\begin{tabular}{|c|c|c|c|c|c|c|c|c|c|c|c|c|c|c|c|}
\hline & & \multicolumn{6}{|c|}{ 低評価群 } & \multicolumn{7}{|c|}{ その他群 } & \multirow{2}{*}{$p$ 值 $^{2)}$} \\
\hline & & 人数 & & 前 & & 後 & $p$ 值 $^{1)}$ & 人数 & & 前 & & & 後 & $p$ 值 $^{1)}$ & \\
\hline \multicolumn{16}{|l|}{ 〈男性〉 } \\
\hline 体重 & $(\mathrm{kg})$ & 17 & 57.6 & \pm 9.3 & 57.3 & \pm 9.4 & 0.355 & 19 & 59.4 & \pm & 8.1 & 59.9 & $\pm \quad 7.8$ & 0.152 & 0.759 \\
\hline BMI & $\left(\mathrm{kg} / \mathrm{m}^{2}\right)$ & 17 & 22.1 & \pm 2.8 & 22.0 & \pm 3.0 & 0.338 & 19 & 23.5 & \pm & 2.9 & 23.7 & $\pm \quad 2.8$ & 0.204 & 0.363 \\
\hline 握力 & $(\mathrm{kg})$ & 16 & 31.0 & $\pm \quad 6.1$ & 32.3 & \pm 6.0 & 0.102 & 17 & 28.7 & \pm & 8.5 & 29.5 & $\pm \quad 8.9$ & 0.181 & 0.769 \\
\hline 開眼片足立ち & （秒） & 9 & 23.9 & \pm 21.8 & 32.7 & \pm 26.6 & 0.252 & 10 & 17.8 & \pm & 17. 2 & 27.2 & \pm 20.6 & 0.137 & 0.510 \\
\hline TUG & （秒） & 16 & 9.9 & $\pm \quad 4.5$ & 8.8 & $\pm \quad 3.9$ & 0.007 & 17 & 9.1 & \pm & 2.9 & 8.9 & $\pm \quad 3.0$ & 0.388 & 0.769 \\
\hline \multicolumn{16}{|l|}{ 〈女性〉 } \\
\hline 体重 & $(\mathrm{kg})$ & 22 & 50.8 & \pm 9.7 & 50.8 & \pm 9.0 & 0.957 & 95 & 50.8 & \pm & 7. 0 & 50.6 & \pm 7.0 & 0.138 & 0.605 \\
\hline BMI & $\left(\mathrm{kg} / \mathrm{m}^{2}\right)$ & 22 & 23.7 & $\pm \quad 3.9$ & 23.5 & \pm 3.6 & 0.330 & 95 & 23.3 & \pm & 3.1 & 23.2 & $\pm \quad 3.1$ & 0.055 & 0.295 \\
\hline 握力 & $(\mathrm{kg})$ & 21 & 18.6 & \pm 4.2 & 18.9 & \pm 4.2 & 0.348 & 85 & 20.7 & \pm & 4. 6 & 21.2 & $\pm \quad 4.2$ & 0.060 & 0.018 \\
\hline 開眼片足立ち & （秒） & 16 & 16.5 & \pm 17.8 & 20.5 & \pm 22.3 & 0.174 & 66 & 28.5 & \pm & 22.5 & 31.1 & \pm 22.7 & 0.139 & 0.023 \\
\hline TUG & （秒） & 21 & 11.9 & $\pm \quad 4.9$ & 10.3 & \pm 3.7 & 0.013 & 85 & 8.6 & \pm & 2.1 & 8. 0 & \pm 1.8 & $<0.001$ & 0.005 \\
\hline
\end{tabular}

平均土標準偏差

1 ) 対応のある $t$ 検定 : プログラム実施前後の比較

2 ) 対応のない $t$ 検定 : プログラム実施前の群間比較

有意に改善した $(p<0.001)$ 。その他群は食事内容の各 項目，得点ともにプログラム実施前後の差は男性同様, 認められなかった。食生活状況の各項目は，低評価群。 その他群ともにプログラム実施前後に有意差はみられず， 食生活状況得点も同様に有意差はみられなかった。

\section{（3）低評価群とその他群のプログラム実施前後の身体 状況・運動器機能の変化}

低評価群とその他群別にプログラム実施前後の身体状 況・運動器機能の変化を表 5 に示した。

プログラム前の測定結果を介護予防マニュアル改訂版 の二次予防事業対象者の評価表 ${ }^{2)}$ より 5 段階で評価（レ ベルが高くほど良好）すると, 男性の握力は低評価 群 レベル 4, その他群 レベル 3, 開眼片足立ち 各々 レベル $5 \cdot 4$, TUG 各々レベル 3・3, 女性の握 力 各々レベル $3 \cdot 4$, 開眼片足立ち 各々レベル $4 \cdot 5$ TUG 各々レベル $2 \cdot 4$ であった。プログラム後には男 性の低評価群の TUG，その他群の握力，開眼片足立ち， TUG がレベル 1 上昇した。総じて評価基準の平均より ややレベルの高い集団であった。

プログラム前の低評価群とその他群の身体状況・運動 器機能について比較した結果, 男性は差が認められな かったが，女性は低評価群の握力，開眼片足立ち（以上 $p<0.05)$ ，TUG $(p<0.01)$ が有意に不良であった。

体重・BMI は低評価群・その他群，男女ともにプログ ラム実施前後の変化は認められなかった。

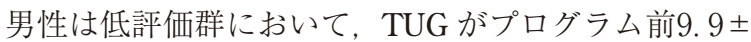
4.5秒, プログラム後 $8.8 \pm 3.9$ 秒に短縮され, 改善が認 められた $(p<0.01)$ 。女性は低評価群に打いて TUG が プログラム前 $11.9 \pm 4.9$ 秒，プログラム後 $10.3 \pm 3.7$ 秒に $(p<0.05)$ ，その他群においても TUG がプログラム前 $8.6 \pm 2.1$ 秒，プログラム後 $8.0 \pm 1.8$ 秒に短縮され（ $p<$ 0.001)，改善が認められた。

\section{4. 考察}

本研究の低評価群は低体重（BMI<18.5）の者が男性 14.3\%，女性13.3\%扔り（表 3)，二次予防事業対象者 8. $3 \%{ }^{13)}$ より高值であり，低栄養のリスクのある高齢者 が多いと推測される。

低評価群は男女ともに油を使った料理の摂取頻度が高 くなり, 男女ともに食事内容全体を示す食事内容得点も 改善していた。さらに，「食事を楽しく食べていますか」, 「現在の食生活をどのように思いますか」を得点化した 食生活状況得点は, 男性で改善していたが女性では改善 はみられなかった。

深作ら ${ }^{9)}$ の研究では, 運動と栄養によるプログラムに より食品摂取が多様化し, 特に魚介類・肉類・卵の主菜, 果物，油脂類などの摂取頻度が改善していた。馬庭ら ${ }^{11)}$ の運動・食習慣の改善支援の介護予防プログラムによる 研究では, 牛乳介入群以外の通常の介入でたんぱく質, 脂質の撖取量が上昇し，食品別にみると主菜になる肉 · 魚 ·卵・大豆, 牛乳・乳製品, 野菜の摂取量が増加して いた。田口ら ${ }^{10)}$ の運動器機能向上・栄養改善の複合プロ グラムによる研究では，主食・主菜を食べる量が良好な 者の割合は増加し，食べる気力・楽しみ，食事への関心 が良好な者の割合も増加していた。これらの研究結果は 詳細な調査項目は異なるものの, 本研究の低評価群と同 様な結果であった。これら先行研究は栄養改善を含む複 合プログラムに参加したすべての対象者を集計したもの であり，どの階層の対象者に改善効果があったかは分析 されていないが，食事内容や食生活状況が低評価の者に 改善効果が大きかったのではないかと推測される。また 西岡ら ${ }^{14)}$ の研究では, 運動トレーニングを行う高齢者の トレーニング効果は初期值が低いものほど大きく、本研 究の食事内容や食生活状況でも同様に低評価群で改善効 果が大きくなったと考えられる。 
本研究でプログラム前の身体状況および運動器機能に ついて調べたところ，女性の低評価群はその他群に比較 し, 握力, 開眼片足立ち, TUG が不良であった。地域 在住高齢者を対象とした研究では，西川ら ${ }^{15)}$ は栄養と運 動器機能は相関があることを報告し，櫂ら ${ }^{16)}$ は栄養の指 標として血清アルブミン值を用い，低栄養状態にある高 齢者は生活習慣と健康状態が全般的に不良であり，握力 と膝伸展力が低下していることを明らかにした。熊谷 $ら^{17)}$ は食品の摂取頻度の増加により血清アルブミンが増 加したと報告しており, 食事内容と血清アルブミンは正 の関連があることを示している。これらのことより，本 研究の低評価群は血清アルブミン值が低い可能性が高く, それらは運動器機能が不良であることは櫂らの研究16) と 一致する。さらに西川ら ${ }^{15)}$ は栄養や運動器機能は主観的 幸福度と関連していることを報告し，西岡ら ${ }^{18)}$ は BMI を栄養の指標とし，栄養状態が良好な者ほど精神的 QOL は高いことを示した。本研究では調査していないが, 低評価群と比較してその他群は QOL が高い可能性があ る。

熊谷ら ${ }^{19)}$ は 5 年間の追跡調査の結果, 多様な食品を摂 取することが高次生活機能の自立の低下を予防すると報 告している。本研究の低評価群も食事内容得点が改善し, 介護予防につながると考えられる。さらに，追跡調査を 行い検討したい。

栄養改善を含む複合プログラムの介入研究では馬庭 $ら^{11)}$ と田口ら ${ }^{10)}$ によると開眼片足立ち, TUG, $5 \mathrm{~m}$ 歩行

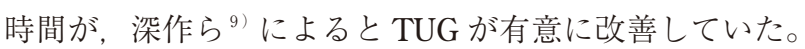
本研究では運動機能のうち TUGは低評価群の男女に, その他群の女性に改善効果が認められた。これは対象者 の 9 割が運動・栄養・ロ腔の複合プログラムに参加して おり（表 1 ），運動プログラムの影響であるか，栄養状 態がよくなったことによる運動器機能の影響であるかは 不明であり，今後明らかにしていきたい。TUGは日常 生活でよく用いられる動作で, 椅子からの起立と直線歩 行，方向転換から直接歩行，方向転換から椅子への着座 を行い, 生活機能の向上を図るために必要な動作である。 これが改善することは, 日常生活動作の改善や転倒リス クの減少につながり ${ }^{20)}$, 本研究対象者, 特に低評価群は 介護予防になると推測される。

本研究は有効回答率が $29.1 \%$ と低く, プログラム参加 者のすべてを代表しているとは言い難い。有効回答率の 低い理由は, 参加者の体調や家庭の事情によるアセスメ ント時の欠席, プログラムの中断, 未回答などである。 要介護・要支援一歩手前の者であるため, 体調の変化や 家族の介護等の影響を受けやすい。しかし，これまでの 栄養プログラムの研究 ${ }^{8-11)}$ では， 1〜2市町のプログラ ムを対象とし，人数は最大で161名であった。本研究は 6 市町203名を対象とし, 幅広い地域の多人数を対象と していることに価值がある。

しかし, 本研究では多地域を対象としたため, プログ
ラムの詳細な内容, 例えば自宅で実施する課題や各自で たてた目標のプログラム中の評価法を一定にできなかっ た。市町で実際に行われている二次予防事業の中でデー 夕を提供していただいたため，市町や実施事業所により， 地域が抱える課題や環境, 設備, 人材が異なってお $り^{1,21)}$, 詳細なプログラム内容を統一することが難しかっ た。しかし，実際に市町で行っている二次予防事業での データであり，実証的研究である。

現在, 厚生労働省は介護予防・日常生活支援総合事業 への移行を進めている。この総合事業は, 市町村が中心 となり，地域の実情に応じて，住民等の多様な主体が参 画し，多様なサービスを充実することで，地域の支え合 い体制づくりを推進し，効果的かつ効率的な支援等を可 能とすることを目指すものである ${ }^{22)}$ 。高齢者の教室へ参 加している地域在住高齢者は摂食規律性を保ち, 毎食規 則正しく，主菜を十分摂っていた ${ }^{23)}$ 。また，介護予防事 業で転倒予防教室などを提供後, 自主グループとしての 活動を継続するよう支援した結果, 介護保険認定率が低 下した報告 ${ }^{24)}$ や，住民主体のサロンや転倒予防教室など の活動が医療費，介護費を抑制した報告 ${ }^{25}$ がある。住民 主体の栄養改善に関する教室の報告がないことより，今 後, 住民の自主的な栄養改善教室による栄養改善の効果 や，さらには介護予防の目的である介護保険認定率，医 療費, 介護費などについて教室に参加してない者を対照 群とし，数年にわたる縦断研究により検討したい。

\section{5. 要 約}

本研究では, 介護予防事業における栄養改善および複 合プログラム参加者203名を対象として, 食事内容を低 評価群とその他群に分類し，3 か月間のプログラム実施 による食事・食生活と運動器機能の改善効果を比較検討 した。

その結果，食事では，低評価群は男女ともに油を使用 した料理の摂取頻度が高くなり，男女ともに全般的な食 事内容を示す食事内容得点が改善していた。さらに, 男 性に「食事を楽しく食べていますか」「現在の食生活を どのように思いますか」を合わせた食生活状況得点が改 善していた。その他群に改善効果はみられなかった。身 体状況と運動器機能では, 体重と BMI は低評価群・そ の他群ともにプログラム実施前後の差はなかった。低評 価群は男女ともに，その他群は女性でTUG が改善して いた。

以上のことから，低評価群では栄養改善および複合プ ログラムを実施したことにより食事・食生活・運動器機 能が改善し, プログラム実施効果がみられ, 介護予防に つながる可能性が示された。

なお, 本研究は広島県からの受託研究「広島県統一評 価項目データ収集・分析事業」の一環として実施した。 


\section{謝 辞}

本研究の実施にあたりご協力いただきました対象者の 皆様，広島県健康福祉局介護保険課，市町および介護予 防事業委託事業者の皆様に厚くお礼申しあげます。

\section{文献}

1）内閣府：平成 27 年版高齢社会白書, http://www8.cao. go.jp/kourei/whitepaper/w-2015/zenbun/pdf/1s1s_1.pdf （2016.4.6アクセス）

2）介護予防マニュアル改訂委員会：平成 23 年度老人保健事 業推進費等補助金（老人保健健康増進等事業分）介護予防 事業の指針策定に係る調査研究事業 介護予防マニュアル 改訂版, 三菱総合研究所, 東京, p. 4, p.38-45, p.50, p.71 -80 (2012)

3 ) Paillaud E, Herbaud S, Caillet P, Lejonc JL, Campillo B, Bories PN: Relations between undernutrition and nosocomial infections in elderly patients, Age Ageing, 34, 619-625 (2005)

4 ) Spaccavento S, Del Prete M, Craca A, Fiore P: Influence of nutritional status on cognitive, functional and neuropsychiatric deficits in Alzheimer's disease, Arch Gerontol Geriatr, 48, 356$360(2009)$

5 ) Tamakoshi A, Yatsuya H, Lin Y, Tamakoshi K, Kondo T, Suzuki S, Yagyu K, Kikuchi S: JACC Study Group: BMI and all-cause mortality among Japanese older adults: findings from the Japan collaborative cohort study, Obesity, 18, 362-369 (2010)

6 ) Knudtson MD, Klein BE, Klein R, Shankar A: Associations with weight loss and subsequent mortality risk, Ann Epidemiol, 15, 483-491 (2005)

7 ）鵜川重和，玉腰暁子，坂元あい：介護予防の二次予防事 業対象者への介入プログラムに関する文献レビュー，日本 公衆衛生雑誌，62，3-19（2015）

8 ）久喜美知子, 新野直明：在宅虚弱高齢者の栄養改善プロ グラムの検討，老年学雑誌， 2，15-30（2012）

9）深作貴子，奥野純子， 戸村成男，清野諭，金美芝，藪下 典子, 大藏倫博, 田中喜代次, 柳久子：特定高齡者に対す る運動及び栄養指導の包括的支援による介護予防効果の検 証，日本公衆衛生雑誌，58，420-432（2011）

10）田口孝行，廣瀬圭子，丸橋悦子：運動機能向上 - 栄養改 善介護予防複合プログラムの開発とその効果, 理学療法 : 臨床・研究・教育, 20, 37-42 (2013)

11）馬庭瑠美, 岩本麻実子, 山崎雅之, 塩飽邦憲：牛乳およ び乳製品摂取による高齢者の介護予防効果に関する研究, 日本農村医学会雑誌， 61，77-87（2012）

12）広島県健康福祉局介護保険課：広島県介護予防実践又 ニュアル〜広島県統一評価項目の実践〜, p. 8-18（2013） http://www.pref.hiroshima.lg.jp/site/kaigoyobou/kaigoyobo ujissemanyuaru.html（2016.4.7アクセス）

13）「介護予防マニュアル」分担研究班：栄養改善マニュアル (改訂版), p.13, p.42-45 (2009), http://www.mhlw.go.jp/ topics/2009/05/dl/tp0501-1e_0001.pdf（2016.4.8アクセス）

14）西岡奈保，田中紀子，平野直美，中村満：介護予防とし てトレーニングを行っている高齢者の身体機能の向上と栄 養蛽取状況について, 日本栄養·食糧学会誌, 66, 9-15, 2013

15）西川秋子, 小石真子：ミニデイサービスに参加する独居 女性高齢者の要介護リスクと主観的幸福感の関連一必要と される介護予防プログラムの作成を目指して一，日本健康 医学会雑誌，23，117-124（2014）

16）權珍嬉，鈴木隆雄，金憲経，吉田英世，熊谷修，吉田祐子, 古名丈人，杉浦美穂：地域在宅高齢者に打ける低栄養と健 康状態掞よび体力との関連，体力科学，54，99-106（2006）

17）熊谷修, 柴田博, 渡辺修一郎, 鈴木隆雄, 芳賀博, 長田 久雄，寺岡加代：自立高齢者の老化を遅らせるための介入 研究 有料老人ホームにおける栄養状態改善によるこころ み，日本公衆衛生雑誌，46，1003-1012（1999）

18）西岡奈保, 田中紀子, 平野直美, 中村満：介護予防とし てトレーニングを行っている高齢者の身体機能の向上と栄 養摂取状況について, 日本栄養·食糧学会誌, 66, 9-15(2013)

19）熊谷修, 渡辺修一郎, 柴田博, 天野秀紀, 藤原佳典, 新 開省二, 吉田英世, 鈴木隆雄, 湯川晴美, 安村誠司, 芳賀博 : 地域在宅高齢者における食品摂取の多様性と高次生活機能 低下の関連，日本公衆衛生雑誌，50，1117-1124（2003）

20）我満衛, 奥本怜子, 西畑満純, 伊藤紀恵, 㷌山ゆかり, 大和優子, 黒田岳雄, 大瀧美惠：Time Up \& Go test に影響 を与える運動機能因子の検討, 総合健診, 41, 586-590 (2014)

21）広島県健康福祉局高齢者支援課：平成24年度介護予防事 業（地域支援事業）の実施状況に関する調査結果（広島県版） 各市町別 調査結果資料編, https://www.pref.hiroshima. lg.jp/uploaded/attachment/115966.pdf（2016.4.8アクセス）

22）厚生労働省老健局振興課：介護予防 - 日常生活支援総合 事業ガイドライン (概要), http://www.mhlw.go.jp/file/06Seisakujouhou-12300000-Roukenkyoku/0000088276.pdf (2016.4.8アクセス)

23）丸山智美，森田一三，中垣晴男：地域在宅高龃女性の食 事摂取調査，日本食生活学会誌，17，348-353（2007）

24）新開省二，吉田裕人，藤原佳典，天野秀紀，深谷太郎， 李相倫, 渡辺直紀, 渡辺修一郎, 熊谷修, 西真理子, 村山 洋史，谷口優，小宇佐陽子，大場宏美，清水由美子，野藤悠 岡部たづる, 干川なつみ, 土屋由美子：群馬県草津町にお ける介護予防 10 年間の歩みと成果, 日本公衆衛生雑誌, 60 596-605 (2013)

25）吉田裕人，藤原佳典，天野秀紀，熊谷修，渡辺直紀，李 相侖, 森節子，新開省二：介護予防事業の経済的側面から の評価 介護予防事業参加群と非参加群の医療 - 介護費用 の推移分析，日本公衆衛生雑誌，54，156-167（2007） 